\title{
Critical Success Factors in Public-Private Partnership
}

\author{
Sri Mulyani \\ Faculty of Economics and Business \\ Universitas Padjadjaran
}

\begin{abstract}
Public-Private Partnership (PPP) is an alternative solution for the government to provide public goods and services that the government cannot fulfil due to budget constraints. However, not all PPP implementations are successful. In this article, the determinants of the success of PPP implementation are examined. The analysis was carried out based on articles discussing the keys success factors of implementing PPP. These articles are taken from articles published in reputable journals. The analysis results show that organizational factors, interactional factors, structural factors, and external factors are the critical factors for PPP implementation's success.
\end{abstract}

Keywords: Public-private partnership, Critical success factors, Public goods and services, Infrastructure

\section{Introduction}

All countries need infrastructure to support the development and improvement of the country's economy. This infrastructure development requires a large fund. However, not all countries can independently finance infrastructure development. The Asian Development Bank (ADB) estimates the annual deficit/gap in economic (hard) infrastructure funding in 25 developing countries in Asia for the period 20162020 is $\$ 459$ billion or $2.4 \%$ of the Gross Domestication Product GDP) of these countries. If the need for social (soft) infrastructure is also considered, the deficit will be $\$ 907$ billion. Economic (hard) Infrastructure is Infrastructure for transportation, energy, water, sanitation and telecommunications.

Meanwhile, social (soft) Infrastructure is Infrastructure in health, education and other social infrastructure. The deficit/gap in infrastructure funding is the difference between infrastructure investment needs and actual investment for infrastructure for one year. The most significant deficit for economic infrastructure occurs in the transportation sector, followed by the energy, water, sanitation and telecommunication sectors. As for social infrastructure, the enormous infrastructure deficit/gap occurs in the education sector, followed by the health sector ( $\mathrm{Ra}$ and $\mathrm{Li}, 2018$ ).

The deficit/gap in infrastructure funding, especially in developing countries, will continue as long as the government cannot increase fiscal revenues that can be used for infrastructure funding. Increasing the government's fiscal capacity takes quite a long time, while infrastructure needs to increase in line with the government's development programs. Several options to overcome this are borrowing money, reallocating budgets, and encouraging private sector investment (Secrieru et al., 2009). Private sector investment can be carried out through a government cooperation scheme, namely the Public-Private Partnership (PPP).

The cooperation scheme helps the government provide the necessary infrastructure without spending many funds because the private sector will finance it. Public-Private Partnership is defined as a collaboration between the public and private sectors for a certain period to develop or provide public goods or services by sharing the risks, costs and resources for the development of these products or services (Van Ham and Koppenjan, 2001; Weihe, 2005). Public-Private Partnership scheme can take partnerships, outsourcing, entrepreneurship partnerships, and joint ventures (Weihe, 2005). 
Cooperation to provide public goods and services in PPP is currently implemented in almost all countries. Public goods or services, including the PPP scheme's infrastructure, are in the transportation sector followed by the energy sector. The PPP scheme assists the government in funding infrastructure development and providing public goods and services and provides another advantage, namely a focus on performance (Warsen et al. 2018). Teisman and Klijn (2002) explain that PPP also describes collaborative governance, cooperation, trust, and horizontal coordination. The non-government parties involved in PPP can be a consortium of contractors and banks/investors. Every party involved in PPP bears the risk, so transparency in contracts and accountability and governance in decision-making are urgently needed (Hodge and Greve, 2007). However, perceptions of governance can differ between the government and the private sector (Cheung et al., 2012; Warsen et al., 2018).

The bureaucratic government, the perspective and governance mechanisms usually applied is hierarchic governance. Meanwhile, the profit-oriented private sector, perspective, and governance mechanisms applied is marketoriented governance (Gestel et al. 2012). The PPP cooperation scheme also demands an exchange of information between cooperating parties (transparency) and an agreement on the purpose of cooperation, product specifications, and certainty of product absorption (Teisman and Klijn 2002). If this is not in the PPP cooperation scheme, then there is a big possibility that the PPP will fail. Apart from these factors, other factors can implement the PPP succeed or fail. Based on the description above, this paper will examine what factors are the keys to implementing PPP's success. The study was carried out on the literature related to the topic which was published in reputable journals.

\section{Literature Review}

\section{Public-Private Partnership}

The concept of Public-Private Partnership (PPP) has been in use since the late 1970s. However, most researchers explain that the UK Labor Government first introduced the PPP concept in the late 1990s. Researchers define PPP with a variety of approaches. Van Ham and Koppenjan (2001) defines PPP as a cooperation between the public and private parties within a certain period to jointly develop a product or service and share the risks, costs and resources associated with these products or services. Zheng et al. (2008) explain that PPP is an agreement whereby the private sector works on long-term infrastructure projects following the output specifications required by the government, then operates and manages them. Bovaird's (2004) defines PPP as a work agreement based on a joint commitment between public sector organizations and nonpublic sector organizations. Grimsey and Lewis (2004) explain that PPP is an agreement between organizations to provide public goods and services. Other researches define PPP from various perspectives but generally lead to the cooperation between the government and nongovernmental organizations in providing public goods and services bound in an agreement.

\section{Public-Private Partnership Framework}

The framework of the Public-Private Partnership (PPP) can be seen in many aspects. Brinkenhoff and Brinkenhoff (2011) describe the PPP framework based on its objectives. In general, PPP implementation aims to design and monitor public policies, provide public services, provide infrastructure, carry out capacity building, and develop the economy. This scope and framework of PPP are also the objectives of implementing PPP by the government. Meanwhile, Zou et al. (2008) describe a PPP framework based on a risk management cycle. According to Weihe (2006), the PPP framework can also be viewed from the defining PPP approach where there are five approaches, namely: the local regeneration approach, policy, infrastructure, development, and governance.

In a PPP arrangement, the parties can combine several of these approaches outlined in the cooperation contract. Liu et al. (2014) explain the PPP framework based on its implementation stages, namely project design and selection of alternative procurement, including Build- 
Operate-Transfer; Build-Transfer-Operate; Build-Own-Operate. Another opinion expressed by Delmon (2015) is that there are five elements in the PPP framework: law, institutional, procurement process, government funding, and long-term funding mobilization.

\section{Governance in Public-Private Partnership}

The PPP agreement is a complex long-term agreement between the government and the private sector covering project design, construction, operation and maintenance; marketing; and finance. (Zheng, 2008). A broad scope of activities and a prolonged period requires good governance in the implementation of the agreement. Good governance in PPP will be realized if there is mutual trust between the parties involved, which must be built from PPP implementation (Koppenjan, 2009). It must also be carried out in every PPP implementation stage based on the parties' agreement in the PPP. Hodge (2006) explains that interlinked funding, a consortium of project implementers, sharing of risks among project implementers, making decisions based on the parties' agreement, will encourage good governance in implementing the PPP.

Self-regulating networks built by the PPP implementers will also create coordination and encourage good governance in PPP implementation (Dunn and Suter, 2009). Projects are undertaken under the PPP scheme usually require large funds, so banking involvement is urgently needed. Also, assurance from the government of market certainty is required to have financial feasibility. The relationship between banking, private sector and government in implementing PPP will also encourage PPP to be appropriately managed (Hodge and Grece, 2007). Brinkenhoff and Brikenhoff (2011) explain that PPP implementation that involves several parties will increase transparency, accountability, reduce corruption, and respect human rights.

Critical Factors for the Success of a PublicPrivate Partnership
Public-Private Partnerships are currently being carried out in many countries as an alternative in providing public goods and services, but not all PPPs are successful in their implementation. The following factors contribute to the success of PPP implementation and factors that cause PPP failure if they are not present in the PPP implementation. These factors include a transparent process, a competitive and effective auction process, business feasibility, a return that is commensurate with the risks, guarantees from the government, risk sharing, stable government policies, presence of markets, good economic conditions, presence of trust, reputation, motivation, as well as good governance, and compliance with environmental preservation standards (Forrer, 2010).

Meanwhile, Ismail (2013) explains that the key to successful PPP implementation is good governance, commitment from both parties, a clear legal framework, supportive economic policies and ease of obtaining funding. Based on their research results, Osie-Kyei and Chan (2015) stated that the key to successful PPP implementation is allocating and sharing risks between parties, a strong consortium, and political support from the government, community support, and a transparent procurement process. According to Cheung et al. (2012), the three keys to successful PPP implementation are each party's commitment and responsibility, a strong consortium of private parties involved, and the allocation and sharing of risks between parties fairly.

Another opinion regarding the critical factors for the success of PPP is that of San Martin (2005) that organizational and interactional factors determine the success of PPP. Organizational factors include leadership and managerial experience, human resource management, access to funding. Interaction factors include a cooperation development manual, clarity of each party's roles, teamwork and joint decision making. The need for group interaction is following that stated by Lasker et al. (2001). Apart from group interaction, several other factors also determine the success of the collaboration, namely the availability of resources; understanding of the characteristics of partnerships (recruiting and maintaining partners 
who have resources); good relations between cooperating parties; the characteristics of cooperation (leadership, administration and management, good governance); and external factors (Lasker, 2001). The external factors referred to are community support, government political support. Meanwhile, Hennart and Zeng (2005) stated that structural factors, namely cooperative partner selection, cooperation contract configuration, cooperative participation and sharing of power, are also factors that determine the success of PPP and the formation of collaborative governance (Purdy, 2012; Hardy and Philips, 1998).

\section{Research Methodology}

This paper is a literature review on the determinants of the success of the Public-Private Partnership arrangement. Works of literature were taken from various reputable journal databases, as well as books, and also from seminar paper. Then research results and books were selected according to the topic in this paper. Then a summary is made under the issues being studied.

\section{Discussion}

Public-Private Partnership (PPP) is one way that governments in many countries address the gap between the need for infrastructure and public goods or services compared to the government's budget capacity to provide it. The British government introduced the PPP scheme to implement the New Public Management incentive in late of the 1990s. This PPP scheme involves several parties for its implementation, namely the government and non-government parties, bound in a long-term cooperation agreement to provide public goods or services or infrastructure. The form of a PPP agreement can be various, including joint ventures, BOT, and BTO. Although the forms of PPP agreements can vary, the objective is the same: to efficiently and effectively provide public goods and services needed by the community, and neither party involved in the cooperation will be disadvantaged. Therefore, it is essential to have transparency and accountability from each party in any collaborative decision-making process in the PPP scheme.

Public-private cooperation in the form of PPP is contained in a contract that contains the framework for implementing the PPP. The PPP contract contains objectives, legal rules, project design, the auction process, project management, funding, risk allocation and sharing, project output, and decision-making related to the project. All of these are the PPP implementation framework. The PPP implementation framework is essential so that the parties involved in the collaboration know their respective positions, rights and responsibilities. Public-Private Partnership also requires that all aspects of the PPP framework be implemented with mutual consent and agreement.

The parties involved in implementing PPP are a consortium with the same objectives as stated in the cooperation contract. The consortium demands a self-regulating network from each consortium member in order to create good coordination. Another thing that the consortium also demands is transparency and accountability to create mutual trust among consortium members. This sense of trust is crucial because almost all PPP activities are carried out jointly by consortium members. Trust will also make it easier to reach agreement in the collaborative decision-making process. In addition to trust, each consortium member's commitment is also very much needed so that PPP can run well. Another thing that is also important in the consortium is risk allocation and sharing, a commensurate return with the risk for each consortium member. All of these things will encourage good governance in the implementation of the PPP.

Good governance is one of the critical factors for the success of PPP. Good governance is part of the interaction factor in a PPP. Clarity on each collaborating party's roles, team work, joint decision-making, coordinative participation, risk sharing, commitment from each party, trust, and reputation are also part of the interactional factors in implementing PPP. If these interactional factors are not formed during PPP implementation, it will make PPP fail to achieve the objectives stated in the contract. Apart from 
interactional factors, other factors that are the key to the success of PPP are organizational, structural, and external factors. Organizational factors include leadership and managerial experience, human resource management, and accessibility of funding from each party. This organizational factor is inherent in the organization of each collaborating party. The structural factors consist of the cooperative partner selection process, the competitive and effective bidding process, the cooperative contract configuration design, the legal framework. This structural factor is a prerequisite for the formation of PPP as expected by the government. External factors include political support from the government, community support, good economic conditions. This external factor has to be taken into account by the government before the PPP scheme is offered to parties to work with.

\section{Conclusion}

People welfare is the government's responsibility, which can be achieved by providing public goods and services and adequate infrastructure. However, budget constraints make the government have to find ways to overcome them. One of these ways is through cooperation with non-government parties. The scheme currently implemented in many countries is the PublicPrivate Partnership. The government must plan the PPP scheme well, carry out a feasibility study, conduct the auction openly, and transparently implement PPP. After the PPP partner has been selected, many other factors determine the PPP's success. These factors are structural, organizational, interactional, and external factors. If these four factors are present and implemented adequately, PPP will be successful and vice versa.

\section{References}

Bovaird T. (2004). Public-private partnerships: from contested concepts to prevalent practice. International Review of Administrative Sciences 70(2): 199-215
Brinkerhoff, D. W., \& Brinkerhoff, J. M. (2011). Public-private partnerships: Perspectives on purposes, publicness, and good governance. Public administration and development, 31(1), 2-14.

Cheung, E., Chan, A. P., \& Kajewski, S. (2012). Factors contributing to successful public private partnership projects. Journal of Facilities Management.

Delmon, Jeffrey. 2015. Creating a Framework for Public-Private Partnership Programs : A Practical Guide for Decision-makers. World Bank, Washington, DC. () World Bankplanning and management, 34(1), e142-e156.

Dunn-Cavelty, M., \& Suter, M. (2009). PublicPrivate Partnerships are no silver bullet: An expanded governance model for Critical Infrastructure Protection. International Journal of Critical Infrastructure Protection, 2(4), 179-187.

Forrer, J., Kee, J. E., Newcomer, K. E., \& Boyer, E. (2010). Public-private partnerships and the public accountability question. Public administration review, 70(3), 475-484.

Grimsey, D., \& Lewis, M. K. (2004). The governance of contractual relationships in public private-partnerships. Journal of Corporate Citizenship, 15, 91-109

Hardy, C., \& Phillips, N. (1998). Strategies of engagement: Lessons from the critical examination of collaboration and conflict in an interorganizational domain. Organization science, 9(2), 217-230.

Hennart, J. F., \& Zeng, M. (2005). Structural determinants of joint venture performance. European Management Review, 2(2), 105-115.

Hodge, G. A., \& Greve, C. (2007). Public-private partnerships: an international performance review. Public administration review, 67(3), 545558.

Hodge, Graeme 2006, 'Public-private partnerships and legitimacy', University of New South Wales Law Journal, Forum, vol. 12, no. 2, November 
Ismail, S. (2013). Critical success factors of public private partnership (PPP) implementation in Malaysia, Asia-Pacific Journal of Business Administration, Vol. 5 No. 1, pp. 6-19.

Klijn, Erik-Hans and Geert R. Teisman (2000): Governing public-private partnerships, in Osborne, S. P. (red.) (2000): Public-Private Partnerships: Theory and Practice in an International Perspective, Routledge Advances in Management and Business Studies

Koppenjan, J. F., \& Enserink, B. (2009). Publicprivate partnerships in urban infrastructures: reconciling private sector participation and sustainability. Public Administration Review, 69(2), 284-296.

Koppenjan, Joop F. M., and Bert Enserink. (2009). Public-Private Partnerships in Urban Infrastructures: Reconciling Private Sector Participation and Sustainability. Public Administration Review 69.2 (2009): 284-96.

Lasker, R. D., Weiss, E. S., \& Miller, R. (2001). Partnership synergy: a practical framework for studying and strengthening the collaborative advantage. The Milbank Quarterly, 79(2), 179205.

Liu, T., Chan, A., \& Wang, S. (2014). PPP framework for public rental housing projects in China. In ICCREM 2014: Smart Construction and Management in the Context of New Technology (pp. 573-581).

Osei-Kyei, R., \& Chan, A. P. (2015). Review of studies on the Critical Success Factors for Public-Private Partnership (PPP) projects from 1990 to 2013. International journal of project management, 33(6), 1335-1346.

Purdy, J. M. (2012). A framework for assessing power in collaborative governance processes. Public administration review, 72(3), 409-417.

Ra, Sungsup \& Li, Zhigong. (2018). Closing the Financing Gap in Asian Infrastructure. ADB South Asia Working Paper Series No 57.

San Martín-Rodríguez, L., Beaulieu, M. D., D'Amour, D., \& Ferrada-Videla, M. (2005). The determinants of successful collaboration: a review of theoretical and empirical studies. Journal of interprofessional care, 19(sup1), 132-147.

Secrieru, A., Lopotenco, V., \& Ciumac, E. (2009). Public investments and public-privat partnerships development. In The Ninth International Conference "Investments and Economic Recovery". Economia Seria Management.

Van Gestel, K., Voets, J., \& Verhoest, K. (2012). How governance of complex PPPs affects performance. Public Administration Quarterly, 140-188.

Van Gestel, K., Voets, J., \& Verhoest, K. (2012). How governance of complex PPPs affects performance. Public Administration Quarterly, 140-188.

Van Ham, H., \& Koppenjan, J. (2001). Building public-private partnerships: Assessing and managing risks in port development. Public management review, 3(4), 593-616.

Warsen, R., Nederhand, J., Klijn, E. H., Grotenbreg, S., \& Koppenjan, J. (2018). What makes public-private partnerships work? Survey research into the outcomes and the quality of cooperation in PPPs. Public Management Review, 20(8), 1165-1185.

Weihe, G. (2005, April). Public-private partnerships: addressing a nebulous concept. In 10th International Research Symposium on Public Management (pp. 10-16).

Zheng, J., Roehrich, J. K., \& Lewis, M. A. (2008). The dynamics of contractual and relational governance: Evidence from long-term public-private procurement arrangements. Journal of purchasing and supply management, 14(1), 43-54

Zou, P. X., Wang, S., \& Fang, D. (2008). A lifecycle risk management framework for PPP infrastructure projects. Journal of financial management of property and construction 